\author{
JANCSÁK, CSABA PHD \\ jancsak@jgypk.szte.hu
}

research group leader (MTA-SZTE Oral History and History Education Research Group)

\title{
Family accounts, narratives, social values and history education
}

\begin{abstract}
Youth research in recent years has revealed that, with info-communication tools (smart phones, web 2.0) becoming a part of children's and youths' everyday life, screenager generations spend less and less time on face-to-face conversations both in the family and in their peer group. Influencers and virtual (online) communities are gradually taking over the role to form children's thinking played so far by traditional interpreting communities' (family, peer groups). Youths' exposure or, in other words, vulnerability to hoaxes and manipulative information spread via the Internet is increasing. The premise of our research is that the lack of family discourse on family history and historical events leads to unrelatedness, which results in collective memory fading away. At the same time, the social role of trans-historical values among members of young generations and their effect on guiding young people's behaviour is decreasing. These factors may transform the objectives and function of history as a school subject and history education (as a form of civic education realised in school). In the present study, we explore family discourse on historical events in students' families and issues of students' value orientations. Furthermore, we investigate opinions on social values that may be represented by history as a school subject and students' and teachers' views on the tasks of history education.
\end{abstract}

\section{KEYWORDS}

social values, family, youth, history, history education

DOI 10.14232/belv.2019.4.2 https://doi.org/10.14232/belv.2019.4.2

Cikkre való hivatkozás / How to cite this article: Jancsák, Csaba (2019): Family accounts, narratives, social values and history education. Belvedere Meridionale vol. 31. no. 4. 13-24. pp.

ISSN 1419-0222 (print) ISSN 2064-5929 (online, pdf)

(Creative Commons) Nevezd meg! - Így add tovább! 4.0 (CC BY-SA 4.0)

(Creative Commons) Attribution-ShareAlike 4.0 International (CC BY-SA 4.0)

www.belvedere-meridionale.hu 


\section{INTRODUCTION}

In recent years, factors suggesting that we are living in a world risk society (BECK 1997, 2007, BECK-GRANDE 2007) have been strengthening. Economic and political crises, increasing poverty, new migration flows, political populism gaining strength and technological changes (ICT, web 2.0), create new vulnerabilities for child and youth generations both in Europe (SORTHEIX-PARKERLECHNER-SCHWARTZ 2017) and in Hungary, such as the crisis of freedom, solidarity, empathy, values of autonomy (crisis of universal humanistic values, crisis of European values), and exposure to manipulations of the post-truth era, the "fear industry" (BECK 2007).

The influencing effects of the mass media have become dominant in young people's thinking. Along with the appearance of web 2.0 and smart devices, time spent on talking in the family is decreasing, thus the impact of the family on young people's thinking and value orientations is also decreasing. The role of peer groups has acquired a new significance. In most recent years, real, face-to-face friendship communities have been taken over by virtual interpreting communities of youths and influencers guiding the individual.

As a consequence of all this, in Hungary, school-age children use the Internet and social media as a basic source of information, which thus become fertile grounds for hoaxes, misconceptions, manipulative grouping of information, and claiming false facts. This vulnerability is reinforced by the phenomenon of increasing isolation, seclusion, measured among Hungarian youths (GÁBOR 2012, JANCSÁK 2013), which means that children and young people leave behind the filter system of traditional interpreting communities (family, peer friendship communities) that would restrict the spread of misconceptions and manipulation.

The Hungarian educational system is not prepared to provide answers for this phenomenon. This applies for the school subject of History and Civic Education, which provides civic education within the frameworks of educational documents (National Core Curriculum), with its key task to educate students in grades 8 and 12 of public education (14- and 18-year-olds) into conscious, active citizens. Our earlier studies reveal that history education, due to its textbook-driven nature, performs its function of democratic education to a lesser extent, contents reflecting on civic education issues are absent from history teacher education, and teachers do not feel prepared for this task (JANCSÁK 2018). The National Core Curriculum specifies in detail those social competences and social values the formation of which, and in case of values the presentation/ preservation of which, lies in the core of the task system of education. However, in everyday classroom practice, it is presenting and teaching the textbook material that is realized. Teachers are aware that the transmission of social values and the framework for civic education are created by non-formal and informal education, nevertheless, training-like sensitization, cooperative methods, project-based instruction, research-based teaching and inquiry-based learning receive no emphasis in Hungarian practices ${ }^{1}$.

\footnotetext{
${ }^{1}$ An objective of the Subject Teaching Methodology Program of MTA is to encourage innovation in the field. https://mta.hu/tantargy-pedagogiai-kutatasi-program.
} 


\section{NOTES ON METHODOLOGY}

Relying on the value theories and research findings of INGLEHART (2000), REZSOHAZY (2006), ROKEACH $(1968,1973)$ and SCHWARTZ $(1992,2006)$, in the value interval questionnaire, we specified the question group applied in Hungarian youth research by GÁBOR (2013). The democratic and civic competences to be developed by history teaching as prescribed in the Hungarian National Core Curriculum (NAT) were supplemented. We added a question block investigating democratic competences, critical thinking, historical thinking and values of active citizenship. It should be noted that our study does not depict the entire value field of modern societies in its complexity; this is a characteristic of value sociology studies (VÁRINÉ 1987. 158). When investigating value orientations, we listed those values that we had identified based on the NAT and included them in a question group as closed questions. Although other values may also appear in history classes, this long question group proved to be sufficient for analysis and for drawing conclusions.

The data that serve as the empirical basis for our research was obtained through paper and pencil questionnaires, which we administered among graduating secondary school students in 28 schools in the school year of 2016-2017 ( $\mathrm{N}=875)$ and 2018-2019 $(\mathrm{N}=476)$ and among history teachers in $2017(\mathrm{~N}=171)$. In this research, discourse conducted in students' families, family accounts of historical events and issues of young people's value orientations were investigated. Furthermore, students' and teachers' opinions on role expectations towards history teaching and on social values that can be presented by history as a school subject and preserved as a result of value transfer processes between generations are also examined.

\section{THE LACK OF FAMILY STORIES AND FAMILY NARRATIVES}

Since the 1990s, several studies have been discussing the transformation of family as an institution, especially the transformation of its socializing function; the formation of families' inner structure and its negative impact on the socialization of children and youths are discussed through various approaches and in great detail in the Hungarian literature as well (SOMLAI 1997, 2013, JANCSÁK 2013, KovÁCs 2014). In today's age of instability (SzABÓ 2014), the age of rushing, changes in the world of work in case of parents, (longer working hours or more jobs) result in a reduced amount of time spent together actively on acts of speaking in the family. Our data show that families of graduating secondary school students engage in conversations for less than an hour a day, and conversations usually accompany or supplement traditional family rituals and daily fixed points in the schedule (waking up-having breakfast-leaving home, and then having dinner-preparing for bedtime). Consequently, instead of focused discussions, storytelling and accounts, it is rather casual chatting that takes place, leaving less room for discussing the life stories of closer or more distant ancestors or related historical events.

In our questionnaires, the historical events that we assumed could appear in the conversations of students' families were investigated within one question group. Our premise was that these events mark the historical milestones from the beginning of the 20th century which may function as important value-bearing symbols for the collective (national) memory. 


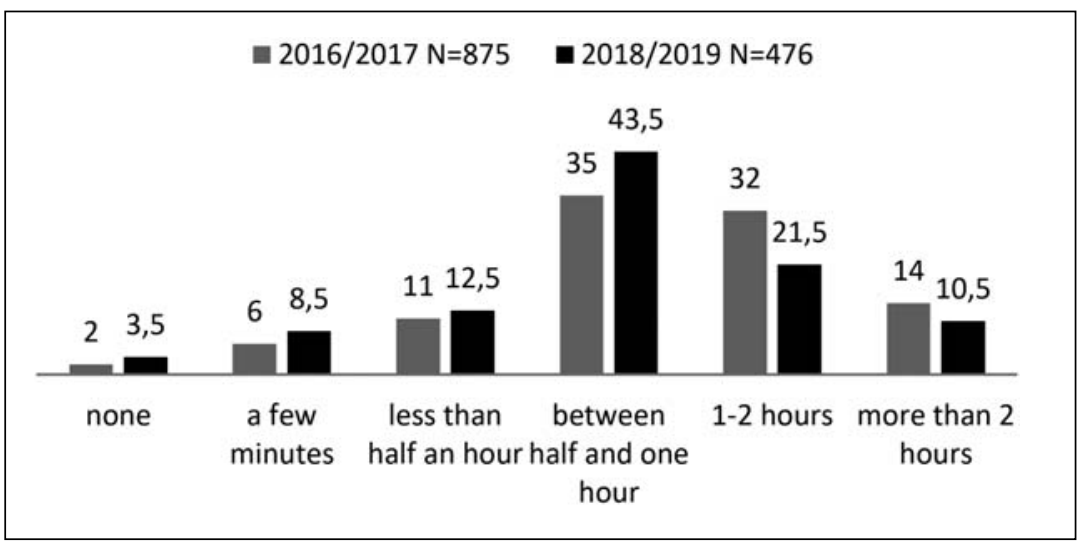

FIGURE 1 How much time do you spend on talking in the family on an avarage day (\%)?

Our research focus was to determine which historical events are talked about in the family circle, regardless of whether the family is personally affected by it or not. All the Hungarian historical turning points or events were included in our questionnaire from Hungary's accession to the European Union back to World War I. Our assumption was that there are only few families with none of their members being affected by any of the listed 20th-century historical events. We specified family member as "ancestor or even remote relative". Our research findings revealed that historical events and historical topics are not discussed in the family in case of nearly one third of the young people.

\begin{tabular}{|l|c|c|}
\hline & $\begin{array}{c}\mathbf{2 0 1 6} / \mathbf{2 0 1 7} \\
\mathbf{N}=\mathbf{8 7 5}\end{array}$ & $\begin{array}{c}\mathbf{2 0 1 8} / \mathbf{2 0 1 9} \\
\mathbf{N}=\mathbf{4 8 2}\end{array}$ \\
\hline Everyday life in the Horthy Era & 30 & 24 \\
\hline World War II & 71 & 63 \\
\hline Holocaust, persecution of Jews & 62 & 49 \\
\hline Soviet occupation, deportation of prisoners of war & 40 & 34 \\
\hline Recsk, internment, show trials & 26 & 25 \\
\hline Collectivization & 45 & 44 \\
\hline Persecution of kulaks & 18 & 18 \\
\hline Everyday life in the Rákosi Era & 32 & 49 \\
\hline 1956 Revolution and War of Independence & 62 & 48 \\
\hline Retaliation after the 1956 Revolution & 41 & 34 \\
\hline
\end{tabular}

TABLE 1 We talked about it in the family in the past year... (\%) 
Further analysing the data, we found no significant differences according to either gender or school type. When considering parents' educational level, we found that families where the father had the highest level of education, i.e. a higher education degree, engaged in conversations about historical events in a smaller proportion, while in the case of mothers, this proportion was more balanced. Conversations about historical events took place in $11 \%$ of families where the father had the highest level of education, while in the case of fathers with a secondary level education, this proportion was $18 \%$.

\begin{tabular}{|l|c|c|}
\hline & Father & Mother \\
\hline Primary school (8 classes) & 10 & 14 \\
\hline Vocational school & 18 & 17 \\
\hline Secondary school graduation (matura exam) & 18 & 15 \\
\hline College, university / Higher education & 11 & 15 \\
\hline
\end{tabular}

TABLE 2 Fathers'/ Mothers'level of education / do you talk about historical events? (YES, \%)

\section{UNRELATED GENERATION (?)}

In our research, we attempted to reveal how young people are related to our historical past through family history and life stories of close or distant relatives and what historical events they know to be related to their families. Our findings reveal that half of the students in their last year before secondary school graduation had no knowledge of their family being related to any historical event. In reflection of the above results (i.e. time spent on conversations in the family), it is hardly surprising, as family stories are typically preserved through discourse conducted between generations, and thus are part of our collective memory as well. The connection between ancestors' life stories and history is preserved in family narratives, which also supports the value transfer processes of trans-historical social values between generations, as in oral historical narratives, there is a marked presence of social value dimensions. We might say that, in this respect, our research findings depict an unrelated generation, whose members do not see historical milestones as valuebearing symbols but as teaching materials to be mastered in history classes. At the same time - based on our earlier discussion - it also means that historical events of our national past disappear from collective memory and become highlighted passages in textbooks to be learned in school, which young people only experience as distant academic knowledge. 


\begin{tabular}{|l|c|c|}
\hline & $\begin{array}{c}\mathbf{2 0 1 6 / 2 0 1 7} \\
\mathbf{N = 8 7 5}\end{array}$ & $\begin{array}{c}\mathbf{2 0 1 8 / 2 0 1 9} \\
\mathbf{N}=\mathbf{4 8 2}\end{array}$ \\
\hline Everyday life in the Horthy Era & 22 & 21 \\
\hline World War II & 51 & 47 \\
\hline Holocaust, persecution of Jews & 11 & 10 \\
\hline Soviet occupation, deportation of prisoners of war & 27 & 23 \\
\hline Recsk, internment, show trials & 9 & 5 \\
\hline Collectivization & 41 & 39 \\
\hline Persecution of kulaks & 13 & 10 \\
\hline Everyday life in the Rákosi Era & 33 & 39 \\
\hline 1956 Revolution and War of Independence & 46 & 37 \\
\hline Retaliation after the 1956 Revolution & 47 & 31 \\
\hline
\end{tabular}

TABLE 3 The family is involved in the event (\%)

\section{HistoriCAL MEMORY AND THE INTRUSION OF GLOBALIZATION}

The first round of our data collection was timed for the months after the 60th anniversary of the 1956 Revolution and War of Independence, as we intended to investigate the world that young people live in with respect to what historical events they discuss in the family and in their peer groups. We asked (in open questions) which historical events they talked about with their friends in the past month. We assumed that graduating secondary school students would talk most about this event in their communities in the time period after the special anniversary, as it is both close to young people's value orientation and it is also projected as "the revolution of youth" in the programs of national memory politics. It is to be emphasised that our respondents were in the last year of secondary school, and according to the framework curriculum for History and Civic Education, these value-saturated topics are to be covered in the final year in the month of October when commemorating historical events and discussing their event history and values serve as important supplements to civic education. Responses to the open question "Which historical events did you talk about in the past month..." are summarised in the table below. We found that young people conducted discussions about the events of 1956 in their families in the time period of the revolution's anniversary (and to some extent, its antecedents and the Kádár Era), however, apart from this, another "historical" event also appeared in family conversations (to a lesser extent) and in conversations with peers (markedly): the US presidential election. In October 2016, a higher proportion of young people talked about the US presidential election with their peers than about the 1956 Revolution. These findings do not only suggest that the world is a reference frame for young people, with what they experience, see, hear or read about pervading their lives, but also at what high level information globalization infiltrates young people's thinking and affects 
their opinions and value orientation. This is exemplified by the fact that, among "historical" events, they list the US presidential election, which was the first to apply those media and media manipulation technologies and techniques which had rewritten the laws of earlier media communication on a global scale and thus became the overture to the era called post-truth.

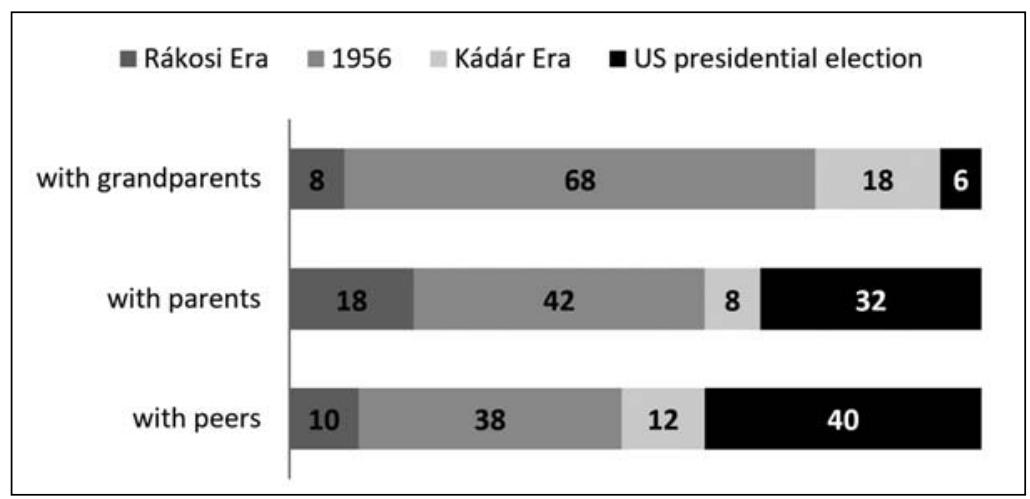

FIGURE 2 Which historical events did you talk about in the past month...?

\section{YOUTHS' VALUE ORIENTATION AND THE VALUES OF HISTORY EDUCATION}

According to value examinations conducted among youths in Hungary, there seem to emerge three eras based on the changes in young people's value orientations. (GÁBOR 2013) From the end of World War II to the mid-eighties, material values (e.g. flat, car, kitchen devices) ranked highest in value preference orders. Post-material values (freedom, solidarity, involvement in decision making, non-conformity, creativity) moved to the top of value preference lists in the following period (increasingly so in the nineties), until the mid-2000s. Then, with another transformation in value preferences, a certain value co-existence appeared with post-material values mixing with postmodern values (such as experimentation, relativity, spontaneity) and a new type of material values (info-communication tools, Internet) and being preferred together with trans-historical values as well (family, happiness, love, friendship, peace). All this demonstrates processes of value crisis/value change, when preferences for certain values, along with their power to determine decisions and actions, fade into the background and are replaced by another value (REZSOHAZY 2006).

In today's Euro-Atlantic civilisation, economic and political crises, increasing poverty, new waves of migration, strengthening political populism and technological changes (ICT, web 2.0, industry 4.0) work towards another value crisis in case of universal humanistic values (freedom, solidarity, altruism). In our research, we also intended to explore what value dimensions appear in the school subject History and Civic Education based on history teachers' opinions, and how they are related to students' value preferences. Our objective was to reveal how teachers describe the world of values of history education (the school subject History and Civic Education). 
The teachers in our study were asked to mark on a scale of 1 to 5 how transferable they consider each value to students within the framework of the subject. The table below presents the value preference rank compiled from the mean scores of teachers' responses. It was concluded that the most important values carried by History as a school subject are freedom, democracy, patriotism, equality before the law, right to make decisions, the nation as a community, respect for traditions and tolerance. What makes these universal values trans-historical in nature is that they are handed down from generation to generation.

\begin{tabular}{|l|c|}
\hline freedom & 4,35 \\
\hline democracy & 4,35 \\
\hline patriotism & 4,32 \\
\hline equality before the law & 4,24 \\
\hline right to make decisions & 4,23 \\
\hline nation as community & 4,22 \\
\hline respect for traditions & 4,16 \\
\hline tolerance & 4,12 \\
\hline conscious citizenship & 4,1 \\
\hline responsibility & 3,94 \\
\hline development & 3,89 \\
\hline solidarity & 3,84 \\
\hline ethics, morals & 3,79 \\
\hline tolerance of religious beliefs & 3,75 \\
\hline peace & 3,72 \\
\hline truth & 3,68 \\
\hline self-sacrifice & 3,68 \\
\hline loyalty & 3,67 \\
\hline sanctity of private property & 3,65 \\
\hline
\end{tabular}

\begin{tabular}{|l|c|}
\hline respect for professional expertise & 3,65 \\
\hline role of science & 3,64 \\
\hline dignity of labour & 3,62 \\
\hline relativity & 3,4 \\
\hline courage & 3,39 \\
\hline family & 3,37 \\
\hline creativity & 3,34 \\
\hline honesty & 3,25 \\
\hline conscious consumption & 3,23 \\
\hline goodwill & 3,14 \\
\hline security & 3,13 \\
\hline benevolence & 3,09 \\
\hline risk-taking & 3,06 \\
\hline true friendship & 2,95 \\
\hline experimentation & 2,68 \\
\hline love and happiness & 2,64 \\
\hline inner harmony & 2,63 \\
\hline politeness & 2,6 \\
\hline
\end{tabular}

TABLE 4 Values of history education. Which values can be transmitted to what extent in history classes? History teachers, mean scores, 1 to 5 scale $(N=171)$

So far, we have presented the power of value-transferring historical accounts in the family along with the consequences of their not taking place, which amplify the educational functions of institutions. This new role expectation from schools is mostly experienced by working groups of humanities teachers in the teaching community, and within that, especially history teachers. At the same time, when presenting trans-historical social values and performing civic education, 
this subject can provide grounds for interdisciplinary concentration, project-based education and research-based education working together with other subjects. However, for this to be realised, there are two necessary conditions: expert-level professional understanding of the knowledge encompassed by the school subject and deep knowledge of subject teaching methodology (see also: BERLINER 2005, JAKAB 2006, KOJANITZ 2018). This is supported by the appearance of crystallised educational objectives with respect to the tasks of the school subject.

In our research, we intended to explore in depth how history teachers view the tasks of history education and how these views are related to students' opinions on the same issue. We concluded that the opinions of the two most important actors (teachers and students) in the educational scenario are the same regarding what they perceive to be the most important tasks of history education, which are its contribution to the preservation of collective memory, to orientation in space and time and to the formation of interpretational frameworks for historical concepts. However, their opinions differ on the interpretation of social processes (social studies) and on factors of individual knowledge management (collecting information), which students definitely consider a task of history education while teachers do so to a lesser extent. It also follows from this that this difference - to a lesser extent, but noticeably - also appears with respect to developing competences necessary for exploring and handling sources and applying source criticism, and also with respect to the introduction of civic competencies and constitutional knowledge, and the functioning of democratic institutions. In a reversed way, there is a considerable gap between opinions on critical thinking, which teachers mark as an important task, while students considered it less important. Through this, the demands of the young generation are manifested, which appear as new expectations from history education. It is to be noted that these factors reflect on the new vulnerabilities presented earlier (e.g. exposure to mass media manipulation), and support orientation in the present. The data also highlight which factors need a higher degree of integration into classroom processes (knowledge about the present) and more developed teaching methodology (individual information gathering and source management).

\begin{tabular}{|l|c|c|}
\hline \multirow{2}{*}{} & \multicolumn{2}{|c|}{$\begin{array}{c}\text { Rank based } \\
\text { on mean scores }\end{array}$} \\
\cline { 2 - 3 } & $\begin{array}{c}\text { History } \\
\text { teachers }\end{array}$ & Students \\
\hline Preserving collective local and national memory & 1 & 2 \\
\hline Developing orientation in space and time & 2 & 1 \\
\hline Developing critical thinking & 3 & 16 \\
\hline Laying foundations for national identity & 4 & 8 \\
\hline Developing correct usage of historical key terms & 5 & 3 \\
\hline Developing historical conceptual thinking & 6 & 4 \\
\hline Developing competences necessary for organising knowledge in a problem-centred way & 7 & 13 \\
\hline
\end{tabular}




\begin{tabular}{|l|c|c|}
\hline & \multicolumn{2}{|c|}{$\begin{array}{c}\text { Rank based } \\
\text { on mean scores }\end{array}$} \\
\cline { 2 - 3 } & $\begin{array}{c}\text { History } \\
\text { teachers }\end{array}$ & Students \\
\hline $\begin{array}{l}\text { Introducing civic competencies and constitutional knowledge, and the functioning } \\
\text { of democratic institutions }\end{array}$ & 8 & 6 \\
\hline Transmitting democratic thinking and patterns of taking actions & 9 & 11 \\
\hline Introducing other cultures and education for tolerance towards them & 10 & 10 \\
\hline Developing competences of basic financial and economic concepts and processes & 11 & 14 \\
\hline Developing competences for managing sources and applying source criticism & 12 & 9 \\
\hline $\begin{array}{l}\text { Developing competences for forming opinions and confronting them in connection } \\
\text { with what was learnt }\end{array}$ & 13 & 15 \\
\hline $\begin{array}{l}\text { Analysing behaviour of historical actors and social groups, examining the operation } \\
\text { of institutions }\end{array}$ & 14 & 18 \\
\hline Analysing social-historical life situations & 15 & 17 \\
\hline Analysing ethical problems & 16 & 19 \\
\hline $\begin{array}{l}\text { Developing students' knowledge about the present and social studies, } \\
\text { developing their social orientation abilities }\end{array}$ & 17 & 5 \\
\hline Raising awareness of values of social justice, equity and solidarity & 18 & 13 \\
\hline $\begin{array}{l}\text { Developing competences for individual information gathering and knowledge } \\
\text { acquisition }\end{array}$ & 7 \\
\hline
\end{tabular}

\section{SUMMARY}

In our study, we presented how it affects family stories that there is a decreasing amount of time spent on conversations in the family, which is necessarily accompanied by the disappearance of value-transfer processes embedded in personal narratives and oral history within the family. As a result, conversations conducted on the milestones of collective memory and the narratives kept alive in this way disappear from young people's interpreting communities (family, peer groups). As the value-transferring effects of symbols carried by historical milestones are disappearing, young people's value orientations are changing and their exposure to new vulnerabilities having appeared in recent years is increasing.

The opinion forming of virtual reference people and interpreting social platforms, and the reception of manipulative media content all have an impact on students' value orientations and structure of value judgements. The phenomenon of value crisis/value change means the devaluation of universal values and the preference of a new type of material values and the preference of individual values. 
Our findings show a divergence in the opinions of teachers, who are more sensitive concerning historical thinking, and new generations still in school, who are exposed to new information vulnerabilities. Our results also identified the new role expectations from history education, as they are defined by youths, concerning how civic education and individual knowledge acquisition are to be supported. At the same time, it was reinforced that history education's contribution to the preservation of collective memory and value transfer processes in case of trans-historical values is highly important. This extended role expectation entails that inter-generational value transfer through oral accounts of history, which is realized to an increasingly smaller degree within the family, should be taken over, to some extent, by history education.

\section{REFERENCES}

Beck, Ulrich - Grande, Edgar (2007): Das kosmopolitische Europa: Gesellschaft und Politik in der Zweiten Moderne. Frankfurt am Main, Suhrkamp.

BECK, UlRICH (1997): Was ist Globalisierung? Irrtümer des Globalismus - Antworten auf Globalisierung. Frankfurt am Main, Suhrkamp.

BECK, ULRICH (2007): Weltrisikogesellschaft, auf der Suhe nach der verlorenen Sicherheit. Frankfurt am Main, Suhrkamp.

BERLINER, DAVID C. (2005): Szakértő tanárok viselkedésének leírása és teljesítményeik dokumentálása. [Describing Expert Teachers' Behaviour and Documenting their Performance.] Pedagógusképzés [Teacher Education] vol. 3. no. 2. 71-91.

GÁBor, KÁLmÁn (2012): Válogatott ifjúságszociológiai tanulmányok. [Selected Studies on Youth Sociology.] Szeged, Belvedere Meridionale.

Inglehart, Ronald (2000): Globalization and Postmodern Values. Washington Quarterly vol. 23. issue 1. 215-228.

JAKAB, GYÖRGY (2006): A történelemtanár dilemmái. (Műveltség és/vagy szakértelem és/vagy kompetencia). [Dilemmas of the History Teacher. Education and/or Expertise and/or Competence.] Új Pedagógiai Szemle [New Pedagogical Review] vol. 56. no.10. 3-21.

JANCSÁK, CSABA (2013): Ifjúsági korosztályok korszakváltásban. [Youth age groups - in the change of an era.] Budapest, Új Mandátum.

JANCSÁK, CSABA (2018): Research-based education development in Hungarian Academy of Sciences - University of Szeged Oral History and History Education Research Group. In BÁNRÉTI, ZOLTÁN et al. (eds.): Results and perspectives. Budapest, Hungarian Academy of Sciences - Belvedere Meridionale. 37-39.

KoJANITZ, LÁSZLÓ (2018): Az elbeszélt történelem forrásainak alkalmazása a történelemórákon. [Using Oral History Sources in History Classes.] Új Pedagógiai Szemle [New Pedagogical Review] vol. 68. no. 9-10. 77-96. 
KovÁcs, GuSZTÁv (2014): Új szülők, új gyermekek. [New parents, new children.] Pécs, PPHF. PÁszKa, ImRe (2010): Sociology of Narrative Story Forms (Life Story, Autobiography). Cluj, Presa Universitara Clujeana.

Rezsohazy, Rudolf (2006): Sociologie des valeurs. Paris, Armand Colin.

Rokeach, Milton (1968): Beliefs, attitudes and values: A theory of organization and change. San Francisco, Jossey-Bass.

Rokeach, Milton (1973): The Nature of Human Value. New York, Free Press.

SchWARTZ, SHALOM (1992): Universals in the Structure and Content of Values: Theoretical Advances and Empirical Tests in 20 Countries. Advances in Experimental Social Psychology vol. 25. no. 1. 1-65.

SchWARTZ, SHALOM (2006): Basic human values: Theory, measurement, and applications. Revue Francaise de Sociologie no. 47. no. 4. 929-968+977+981.

SOMlai, PÉTER (1997): Szocializáció. [Socialization.] Budapest, Corvina.

SOMLAI, PÉTER (2013): Család 2.0. [Family 2.0.] Budapest, Napvilág.

Sortheix, Florencia - Parker, Philip - Lechner, Clemens - Schwartz, Shalom (2017): Changes in Young Europeans' Values During the Global Financial Crisis. Social Psychological and Personality Science vol. 10. no. 1. DOI 10.1177/1948550617732610.

SzABÓ, TiBOR (2014): Az instabilitás kora. [The age of instability.] Szeged, Belvedere Meridionale. VÁRINÉ, SZILÁgyi Ibolya (1987): Az ember, a világ és az értékek világa. [Humans, the world and the world of values.] Budapest, Gondolat Könyvkiadó. 